\title{
Three Types of Vitronectin in Human Blood
}

\author{
Koyomi Kubota, Sumiko Katayama ${ }^{+}$, Michio Matsuda* and Masao \\ Hayashi $^{++}$ \\ Department of Biology, Ochanomizu University, Bunkyo-ku, Tokyo 112, and \\ ${ }^{*}$ Hemostasis and Thrombosis Research Division, Institute of Hematology, \\ Jichi Medical School, Tochigi 329-04, Japan
}

\begin{abstract}
Vitronectin is a cell-adhesive glycoprotein in serum and plasma, also termed serum spreading factor and complement S-protein. It consists of a mixture of a polypeptide of molecular weight 75 kilodalton $(\mathrm{kDa})$ and its nicked product of $65 \mathrm{kDa}$ plus $10 \mathrm{kDa}$. By a quantitative immunoblotting assay, human blood samples could be classified into three distinct vitronectin types; type I ( $58 \%$ of the population) was $75 \mathrm{kDa}$ rich and $65 \mathrm{kDa}$ poor, type II (35\% of the population) contained approximately equal amounts of $75 \mathrm{kDa}$ and $65 \mathrm{kDa}$, and type III (5\% of the population) was $75 \mathrm{kDa}$ poor and $65 \mathrm{kDa}$ rich. The vitronectin type did not correlate with age, sex, or ABO blood type.
\end{abstract}

Vitronectin is a 75 kilodalton $(\mathrm{kDa})$ glycoprotein in plasma and tissue (4), also termed serum spreading factor $(2)$ and complement S-protein $(7,11)$. It promotes attachment and spreading of animal cells in vitro $(2,11)$, inhibits cytolysis by the complement C5b-9 complex (9), and modulates antithrombin III-thrombin action in blood coagulation $(5,6,10,12)$. The concentration of vitronectin in plasma and serum is $0.1-0.4 \mathrm{mg} / \mathrm{ml}(2,4)$, and it does not correlate substantially with age or sex (13). The primary structure of vitronectin has been deduced from its cloned cDNA sequence $(7,14)$. Vitronectin is usually detected as a mixture of $75 \mathrm{kDa}$ and $65 \mathrm{kDa}$ polypeptides $(2-4)$, in which the $65 \mathrm{kDa}$ polypeptide is derived from the amino terminal portion of the $75 \mathrm{kDa}$ polypeptide (15). This paper describes a very sensitive assay for individual $65 \mathrm{kDa}$ and $75 \mathrm{kDa}$ polypeptides and classifies human sera and plasma into three vitronectin types depending on the ratios of $65 \mathrm{kDa}$ to $75 \mathrm{kDa}$ polypeptides of vitronectin.

\section{MATERIALS AND METHODS}

Preparation of vitronectin and anti-vitronectin Antiserum. Human vitronectin and antihuman vitronectin rabbit antibody were prepared as described previously $(1,3)$ or by our recent procedure (17).

Human Serum and Plasma. Human blood was collected from 104 healthy human

\footnotetext{
+ Present address: Molecular Genetics Research Laboratory, University of Tokyo, Bunkyo-ku, Tokyo 113, Japan.

++ To whom correspondence should be addressed at Department of Biology, Ochanomizu University, Bunkyo-ku, Tokyo 112, Japan.

Abbreviation used: $\mathrm{kDa}$, kilodalton.
} 
volunteers, clotted at room temperature for $1 \mathrm{~h}$ followed by incubation at $4{ }^{\circ} \mathrm{C}$ overnight, and centrifuged at $12,000 \times \mathrm{g}$ for $2 \mathrm{~min}$ in a Beckman Microfuge $\mathrm{B}$. The supernatant (serum) was stored at $-80^{\circ} \mathrm{C}$. Blood was also collected randomly from outpatients at Jichi Medical School and immediately anticoagulated with $1 / 10$ volume of $3.18 \%$ trisodium citrate dihydrate. Plasma was harvested by centrifugation at $3,000 \times \mathrm{g}$ for $30 \mathrm{~min}$ at room temperature and stored frozen until use.

Quantitative assay of the $75 \mathrm{kDa}$ and $65 \mathrm{kDa}$ vitronectin polypeptides. For quantitative assay of the $75 \mathrm{kDa}$ and $65 \mathrm{kDa}$ vitronectin polypeptides, the indicated amounts of human plasma and serum were subjected to SDS-polyacrylamide gel electrophoresis according to the method of Laemmli (8) after chemical reduction with $0.1 \mathrm{M}$ dithiothreitol. Immunoblotting was performed essentially according to Towbin et al. (16). The serum proteins separated in the SDS gel were transferred to a nitrocellulose sheet (Schleicher and Schuell, Inc., type BA$85,0.45 \mu \mathrm{m}$ pore size, Keene, New Hampshire) in $5 \mathrm{mM}$ sodium tetraborate at $4^{\circ} \mathrm{C}$ for $90 \mathrm{~min}$ at $90 \mathrm{~V}$ in a Trans-blot cell (Bio-Rad Japan, Tokyo). The nitrocellulose sheet was blocked with $0.2 \%(\mathrm{w} / \mathrm{v})$ skim milk (Yuki-jirushi Milk Co., Tokyo) in phosphate-buffered saline. Vitronectin on the sheet was allowed to react with rabbit anti-vitronectin antiserum at $1 / 3,000$ dilution followed by the second antibody consisting of horseradish peroxidaseconjugated goat antibody against rabbit IgG at 1/1,500 dilution. Color for the bound peroxidase was developed with $34 \mu \mathrm{g} / \mathrm{ml} o$-dianisidine and $0.01 \% \mathrm{H}_{2} \mathrm{O}_{2}$ in phosphate-buffered saline. Two-dimensional densitometry of the $75 \mathrm{kDa}$ and $65 \mathrm{kDa}$ bands on the nitrocellulose sheets was performed with a graphic analyzer Shonic GA (Showa Denko Co., Tokyo) equipped with a personal computer PC-9801F2 (NEC Co., Tokyo) utilizing a custom program termed Sumiko 1. Statistical analysis was performed using the Student's t-test.

\section{RESULTS AND DISCUSSION}

Immunoblotting indicated that the patterns of vitronectin polypeptides in human serum could be readily classified into three types characterized by high, medium, or low ratios of $65 \mathrm{kDa}$ to $75 \mathrm{kDa}$ polypeptides (Fig. 1). The two bands migrated at $80 \mathrm{kDa}$ and $72 \mathrm{kDa}$ in our system, but the terms $75 \mathrm{kDa}$ and $65 \mathrm{kDa}$ are retained for consistency with the previous nomenclature. Individual $75 \mathrm{kDa}$ and $65 \mathrm{kDa}$ polypeptides of vitronectin stained by anti-vitronectin antiserum were quantitated by a twodimensional densitometry of the polypeptide bands on nitrocellulose blots. Figure 2 shows a standard curve expressed as the sum of the $75 \mathrm{kDa}$ and $65 \mathrm{kDa}$ vitronectin polypeptides; the standard deviation was approximately $\pm 10 \%$. The densitometric value increased linearly with the amount of plasma in the range of 25-175 nl, roughly corresponding to 5-35 ng vitronectin. Since staining intensity of the band slightly varied from blot to blot, an internal vitronectin standard of $20 \mathrm{ng}$ was included in every blot in the following experiments.

Systematic quantitative analyses were performed with aliquots of $100 \mathrm{nl}$ of human sera from 104 healthy volunteers as well as $111 \mathrm{nl}$ of human plasma from 100 outpatients. Samples of 202 out of 204 contained detectable amounts of the $65 \mathrm{kDa}$ and/or $75 \mathrm{kDa}$ polypeptides. They were readily classified into three distinct groups according to $65 \mathrm{kDa} /(65 \mathrm{kDa}+75 \mathrm{kDa})$ ratios: $\geqq 0$ and $<0.35$ (type I), $\geqq 0.35$ and $<0.85$ (type II), and $\geqq 0.85$ and $\leqq 1.0$ (type III) comprising $58 \%, 35 \%$, and $5 \%$ of the samples tested, respectively (Figs. 1 and 3 ). This population substantially differed neither between serum and plasma nor between healthy volunteers and outpatients. One of the remaining 2 lots of blood did not contain the $65 \mathrm{kDa}$ or $75 \mathrm{kDa}$ vitronectin, but rather $60 \mathrm{kDa}$ and $52 \mathrm{kDa}$ polypeptides stained by anti- 


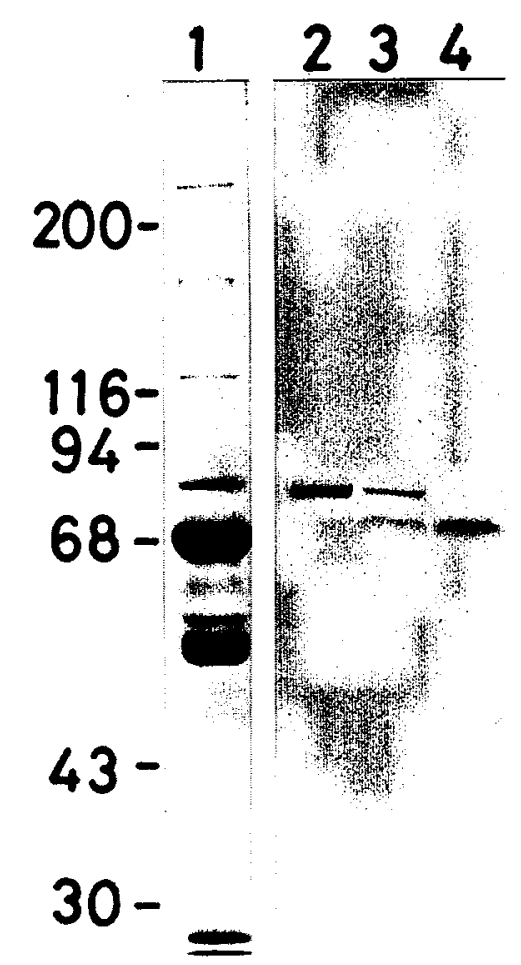

Fig. 1. Immunoblotting of human serum with anti-vitronectin antiserum. Different lots of human sera were immunoblotted and stained with anti-vitronectin antiserum. Samples were chemically reduced with $0.1 \mathrm{M}$ dithiothreitol; typical type I (lane 2), type II (lane 3), and type III (lane 4). Lane 1 shows a typical serum protein pattern stained by Coomassie blue using the same amount of serum protein as for immunoblotting. Size markers (in kilodaltons) are shown at the left.

vitronectin antibody. The other lot of blood contained an approximately 25 -fold lower concentration of vitronectin, and the vitronectin pattern was similar to type III. The three vitronectin types did not correlate with age (subjects were between 21 and 65 years), sex, or ABO blood type.

The total concentration of vitronectin in serum and plasma was estimated as the summation of the amounts of $75 \mathrm{kDa}$ and $65 \mathrm{kDa}$ polypeptides. The concentration differed neither between serum and plasma nor between healthy volunteers and outpatients. The means and standard deviations for vitronectin concentrations were $0.206 \pm 0.079 \mathrm{mg} / \mathrm{ml}$ for type I, $0.196 \pm 0.069 \mathrm{mg} / \mathrm{ml}$ for type II, and $0.176 \pm$ $0.060 \mathrm{mg} / \mathrm{ml}$ for type III, respectively (Fig. 4). However, statistical analysis using the Student's t-test indicated that the difference in the three concentrations was not significant at $\mathrm{p}<0.1$.

The biological importance of the vitronectin type in human serum and plasma is not known, and no functional differences between $75 \mathrm{kDa}$ and $65 \mathrm{kDa}$ polypeptides have been reported. Since the $65 \mathrm{kDa}$ polypeptide appears to be a post-translational cleavage product of the $75 \mathrm{kDa}$ polypeptide $(14,15)$, it is assumed that the $75 \mathrm{kDa}$ vitronectin is degraded to $65 \mathrm{kDa}$ by some protease in the blood. The ratio of 


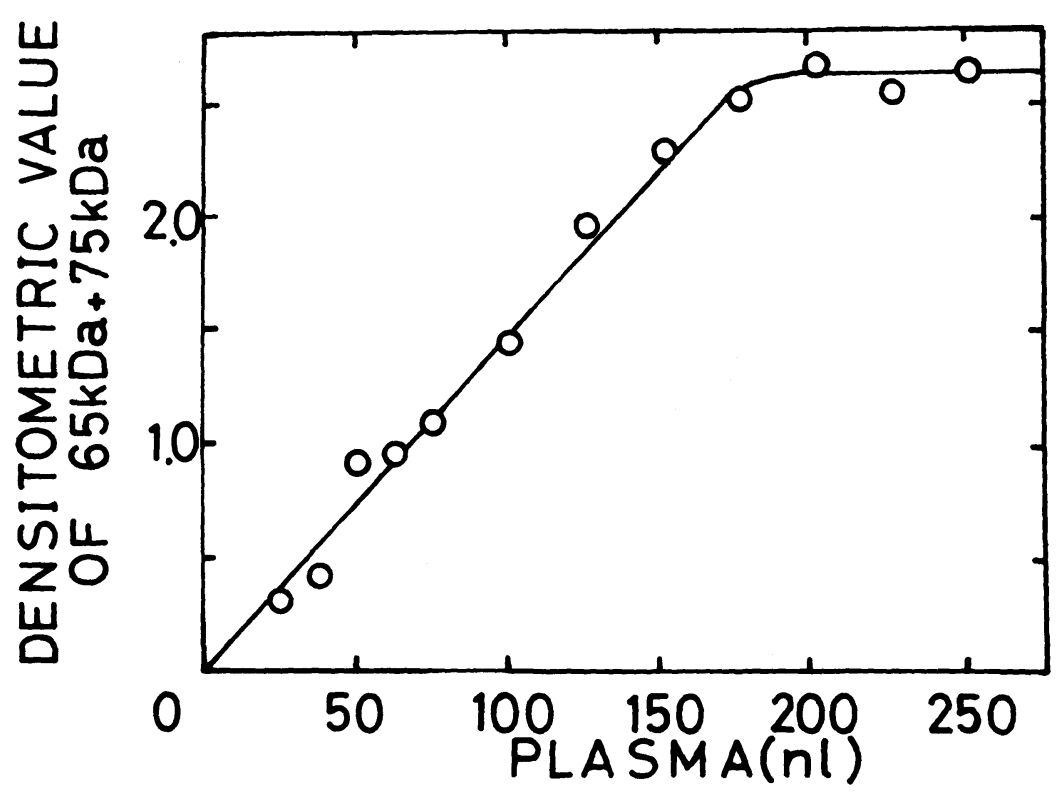

Fig. 2. Standard curve for the vitronectin assay. The indicated amounts of human plasma were immunoblotted. Bands stained by anti-human vitronectin antibody were measured by two-dimensional densitometry and expressed as a summation of the $75 \mathrm{kDa}$ and $65 \mathrm{kDa}$ polypeptides.



Fig. 3. The three vitronectin blood types. The ratios of $65 \mathrm{kDa} /(65 \mathrm{kDa}+75 \mathrm{kDa})$ polypeptides of vitronectin were measured for 104 healthy human sera and 100 outpatient human plasma samples. 


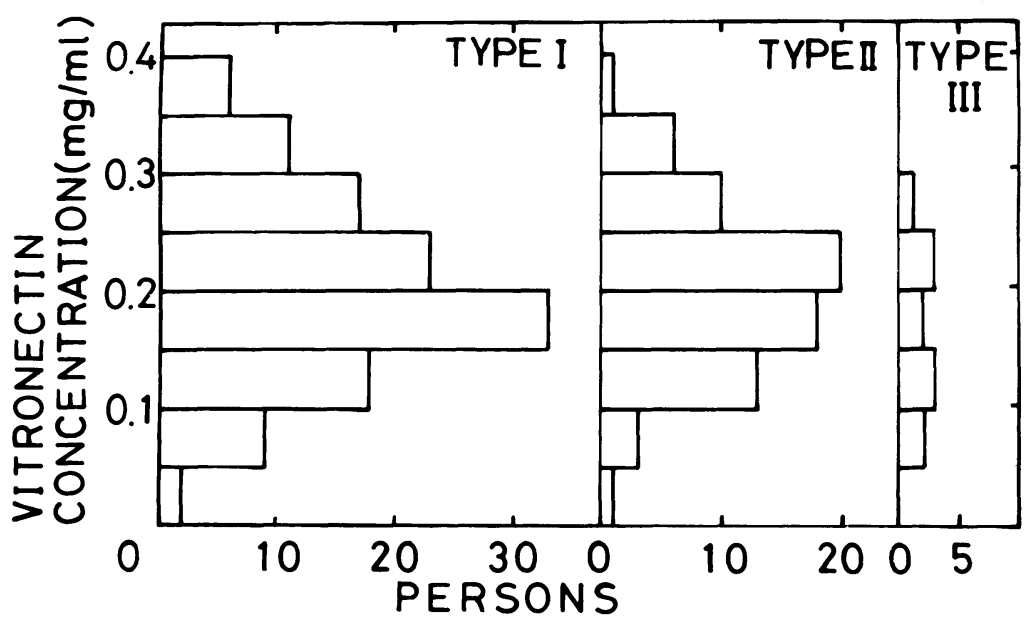

Fig. 4. Total vitronectin concentrations in each of the three blood types. Vitronectin concentrations were determined as a summation of the $65 \mathrm{kDa}$ and $75 \mathrm{kDa}$ polypeptides.

$65 \mathrm{kDa} /(65 \mathrm{kDa}+75 \mathrm{kDa})$ polypeptides did not, however, change during storage of serum at $4^{\circ} \mathrm{C}$ for 3 days, nor at $-20^{\circ} \mathrm{C}$ for at least 6 months with 6 cycles of freezing and thawing.

The vitronectin blood type may reflect the activity of a blood protease cleaving vitronectin $75 \mathrm{kDa}$ to $65 \mathrm{kDa}$, or the presence of two nonidentical $75 \mathrm{kDa}$ polypeptides, i.e., protease-susceptible and nonsusceptible populations. Future biochemical and biological studies of vitronectin should take into account this potential source of variability.

Acknowledgments. We thank Dr. Kenneth M. Yamada (Lab. of Mol. Biol., National Cancer Institute, NIH, USA) for helpful suggestions and Ms. Kazuko Hayashi for secretarial assistance.

\section{REFERENCES}

1. Akama, T., K.M. Yamada, N. Seno, I. Matsumoto, I. Kono, H. Kashiwagi, T. Funaki and M. HAYASH. Immunological characterization of human vitronectin and its binding to glycosaminoglycans. J. Biochem. 100, 1343-1351, 1986

2. Barnes, D.W. and J. Silnutzer. Isolation of human serum spreading factor. J. Biol. Chem. 258, 12548-12552, 1983

3. Hayashi, M., T. Akama, I. Kono and H. Kashiwagi. Activation of vitronectin (serum spreading factor) binding of heparin by denaturing agents. J. Biochem. 98, 1135-1138, 1985

4. Hayman, E.G., M.D. Pierschbacher, Y. Öhgren and E. Ruoslahti. Serum spreading factor (vitronectin) is present at the cell surface and in tissues. Proc. Natl. Acad. Sci. USA 80, 4003-4007, 1983

5. ILl, C.R. and E. RuosLahti. Association of thrombin-antithrombin III complex with vitronectin in serum. J. Biol. Chem. 260, 15610-15615, 1985

6. Jenne, D., F. Hugo and S. Bhakdi. Interaction of complement S-protein with thrombinantithrombin complexes: a role for the S-protein in haemostasis. Thromb. Res. 38, 401-412, 1985

7. Jenne, D. and K.K. StANLEY. Molecular cloning of S-protein, a link between complement, coagulation and cell-substrate adhesion. EMBO J. 4, 3153-3157, 1985

8. LAemmli, U.K. Cleavage of structural proteins during the assembly of the head of bacteriophage 
T4. Nature 227, 680-685, 1970

9. Müller-EberhaRd, H.J. The membrane attack complex. Springer Semin. Immunopathol. 7, 94141, 1984

10. PoDACK, E.R., B. DAHLBÄCK and J.H. Griffin. Interaction of S-protein of complement with thrombin and antithrombin III during coagulation. J. Biol. Chem. 261, 7387-7392, 1986

11. Preissner, K.T., N. Heimburger, E. Anders and G. Müller-Berghaus. Physicochemical, immunological and functional comparison of human S-protein and vitronectin. Evidence for the identity of both plasma proteins. Biochem. Biophys. Res. Commun. 134, 951-956, 1986

12. Preissner, K.T., L. Zwicker and G. Müller-Berghaus. Formation, characterization and detection of a ternary complex between $\mathrm{S}$ protein, thrombin and antithrombin III in serum. Biochem. J. 243, 105-111, 1987

13. ShafFer, M.C., T.P. Foley and D.W. BARNeS. Quantitation of spreading factor in human biologic fluids. J. Lab. Clin. Med. 103, 783-791, 1984

14. Suzuki, S., A. Oldberg, E.G. Hayman, M.D. Pierschbacher and E. Ruoslahti. Complete amino acid sequence of human vitronectin deduced from cDNA. Similarity of cell attachment sites in vitronectin and fibronectin. EMBO J. 4, 2519-2524, 1985

15. Suzuki, S., M.D. Pierschbacher, E.G. Hayman, K. Nguyen, Y. Öhgren and E. Ruoslahti. Domain structure of vitronectin. J. Biol. Chem. 259, 15307-15314, 1984

16. Towbin, H., T. Staehelin and J. GoRdon. Electrophoretic transfer of proteins from polyacrylamide gels to nitrocellulose sheets: procedure and some applications. Proc. Natl. Acad. Sci. USA 76, 4350-4354, 1979

17. Yatohgo, T., M. IzUmi, H. Kashiwagi and M. Hayashi. Novel purification of vitronectin from human plasma by heparin affinity chromatography. Cell Struct. Funct. in press, 1988

(Received for publication, January 16, 1988) 